\title{
MIT VÁRHAT AZ EURÓPAI UNIÓ A VÉGLEGES BÁZEL III ALKALMAZÁSÁTÓL?
}

\author{
Seregdi László
}

A Bázeli Bankfelügyeleti Bizottság 2017 decemberében számos ponton kiegészítette a korábban kiadott Bázel III ajánlását, amelyet Bázel III véglegezés elnevezéssel tett közzé. A kiegészítések a belső modellek alapján számított tőkekövetelmény korlátozására, a hitel- és piaci kockázati módszerek kockázatérzékenyebbé tételére, a működési kockázat tőkekövetelmény-számítási módszereinek egységesítésére, valamint a globálisan rendszerszinten jelentős hitelintézetek tőkeáttételi mutató követelményének emelésére irányulnak. Az Európai Bankhatóság megvizsgálta, hogy ezek a módosítások hogyan érintenék az európai bankokat, illetve javaslatokat tett arra, hogy a módosításokat milyen eltérésekkel lenne indokolt átültetni az EU jogszabályaiba. Az Európai Bizottság ezen adatok és ajánlások figyelembevételével fogja majd megkezdeni az EU-jogszabályok, elsősorban a CRD és a CRR módosítására vonatkozó javaslatainak a kidolgozását.

JEL-kódok: G21, G28, L51, N24, O16

Kulcsszavak: bankszabályozás, EBA, tőkekövetelmények

\section{BEVEZETÉS}

A Bázeli Bankfelügyeleti Bizottság 1975 óta tesz közzé szakmai ajánlásokat, amelyek célja, hogy egységesítsék az egyes országokban a bankokra alkalmazott prudenciális követelményeket és bankfelügyeleti módszereket, ezáltal globális szinten befolyásolják a pénzügyi szektor szabályozási és felügyeleti környezetét. Bár a Bázeli Bizottság (Bizottság) ajánlásainak a betartása nem kötelező, és a Bizottság nem is rendelkezik semmilyen szankcionálási lehetőséggel az ajánlásainak a be nem tartása esetére, de a gyakorlatban a fejlett pénzügyi rendszerrel rendelkező országok mind arra törekednek, hogy betartsák a Bizottság ajánlásaiban foglaltakat.

A Bizottság még 1988 júliusában adta ki a Basel Capital Accord (vagy Bázel I) néven elhíresült ajánlását, amely már tartalmazta a szavatolótőke és a kockázattal

1 Seregdi László a Magyar Nemzeti Bank Szabályozási főosztályán felügyeleti tanácsadó. E-mail: seregdil@mnb.hu. 
súlyozott mérlegfőösszeg kiszámításának a módját és a minimum nyolc százalékos tőkemegfelelési mutató követelményt. Az idők folyamán ezek a módszerek folyamatosan bővültek, és 1996-ban kiegészültek a piaci kockázatok tőkekövetelményével. 2004-ben, már Bázel II elnevezéssel újabb jelentős módosítások következtek, így többek között a müködési kockázat tőkekövetelményének bevezetésével, a felügyeleti felülvizsgálati folyamat elemeinek kialakításával, valamint a belső modelleknek a tőkekövetelmény-számítás használatára történő engedélyezésével. A globális pénzügyi válság azonban rámutatott a korábban kissé engedékeny és laza követelményrendszer hiányosságaira, ezért a Bizottság 2010-ben szigorításokat volt kénytelen végrehajtani, amelyek elsősorban a szavatoló tőkeelemek figyelembevételi szabályainak szigorítására és a tőkekövetelmények emelésére irányultak (Bázel III), valamint célul tűzte ki a teljes ajánlásának a felülvizsgálatát. Ennek a felülvizsgálatnak az eredménye a 2017 decemberében közzétett anyag, amely a Bázel III véglegezés (finalization) elnevezést viseli (BCBS, 2017).

\section{A BÁZEL III VÉGLEGEZÉS FÖBB ELEMEI}

A Bázel III ajánlás véglegezését hosszú szakmai egyeztetés és számos előzetes hatástanulmány előzte meg. A Bizottság fó célja a módosításokkal az volt, hogy csökkentse a kockázattal súlyozott eszközérték változékonyságát, ezáltal megbízhatóbbá tegye a tőkekövetelmények meghatározását. A módosítások hat fő témakör köré csoportosíthatók, ezek az output floor bevezetése, a hitel-, piaciés működési kockázati tőkekövetelmény-számítási rendszer átalakítása, a CVAkockázatra vonatkozó módszer finomítása, valamint a globálisan rendszerszinten jelentős hitelintézetek tőkeáttételi mutató követelményének az emelése.

\subsection{Output floor}

A belső modellek tőkekövetelmény-számításra való felhasználhatóságának engedélyezése során 2004-ben a Bizottság egy eredetileg átmenetinek szánt küszöbértékrendszert vezetett be, amely azt a célt szolgálta, hogy a hitelkockázat vagy a működési kockázat esetében belső modellt alkalmazó bankok tőkekövetelménye a bevezetést követő három évben (2006-2008) ne csökkenhessen a Bázel I alapján számított tőkekövetelmény 95 , 90 és 80 százaléka alá, korlátozva ezzel a belső modell alkalmazásával elérhető tőkekövetelmény-megtakarítást. Bár ez a tőkekövetelmény-korlát az EU szabályozásában hosszabb ideig is fennmaradt, először 2009, majd 2011, végül 2017 végéig meghosszabbítva (EB, 2013), de jelenleg se az EU-szabályozás, se a bázeli ajánlások nem tartalmaznak ilyen korlátot. Az új output floor bevezetésére 2022-től fokozatosan kerül majd sor az alábbi táblázatban foglaltak szerint. 


\section{1. táblázat}

Az output floor fokozatos bevezetése

\begin{tabular}{lcccccc}
\hline Dátum & $\mathbf{2 0 2 2}$ & $\mathbf{2 0 2 3}$ & $\mathbf{2 0 2 4}$ & $\mathbf{2 0 2 5}$ & $\mathbf{2 0 2 6}$ & $\mathbf{2 0 2 7}$ \\
\hline Output floor & $50 \%$ & $55 \%$ & $60 \%$ & $65 \%$ & $70 \%$ & $72,5 \%$ \\
\hline
\end{tabular}

Forrás: Bázeli Bizottság

Az output floor bevezetésének a fö oka: a Bizottság azt tapasztalta, hogy a banki belső modellek eredményei jelentős eltéréseket mutatnak. Ezen eltérések egy része indokolható a bankok portfóliói és üzleti modelljei közötti különbségekkel, de az eltérések jelentős részének nincs érdemi közgazdasági indoka. A belső modellek által adott eredmények ráadásul egy válság esetén nagyon ingadozóak, a nemteljesítési (PD) értékek romlásával gyors ütemben emelkedik a tőkekövetelmény, ez pedig erősíti a prociklikus hatást. A tőkekövetelmény-korlát célja ezért az, hogy a belső modellek eredményei stabilabbá váljanak, és ne adjon lehetőséget túlzott eltérésekre a sztenderd módszerek által számított eredményektől.

\subsection{A hitelkockázat tőkekövetelmény-számítása}

2017 végén a Bizottság mind a hitelkockázati sztenderd, mind a belső modell szerinti tőkekövetelmény-számítást jelentősen átalakította. A sztenderd módszer átalakításának fö elve az volt, hogy kockázatérzékenyebb legyen, illetve alkalmassá váljon az IRB output floorként való felhasználásra is. A Bizottság megpróbálta ösztönözni, hogy a bankok már a sztenderd módszer alkalmazása során is kevésbé támaszkodjanak a külső hitelminősítők által adott értékelésekre. A felülvizsgálat eredményeképpen szigorodnak a részesedésekre, az alárendelt kölcsöntőkére és a bankokkal szembeni kitettségekre vonatkozó kockázati súlyok. Jelentősen átalakítják az ingatlanfedezet mellett nyújtott hitelek kockázati súlyait, amelyeket annak az alapján kell megállapítani, hogy lakó- vagy kereskedelmi ingatlan a hitel mögött álló fedezet, a hitel-visszafizetés forrása az ingatlanból származó bevétel-e vagy sem, illetve hogy mekkora az LTV (loan to value) értéke. 


\section{2. táblázat}

\section{Ingatlannal fedezett kitettségek kockázati súlyai}

\begin{tabular}{|c|c|c|c|c|c|c|c|c|}
\hline \multicolumn{9}{|c|}{ Lakóingatlannal fedezett kitettségek } \\
\hline LTV-arány & $\begin{array}{l}50 \% \\
\text { alatt }\end{array}$ & $\begin{array}{c}50 \%- \\
60 \%\end{array}$ & $\begin{array}{c}60 \%- \\
70 \%\end{array}$ & $\begin{array}{c}70 \%- \\
80 \%\end{array}$ & $\begin{array}{c}80 \%- \\
90 \%\end{array}$ & $\begin{array}{l}90 \%- \\
100 \%\end{array}$ & $\begin{array}{l}100 \% \\
\text { felett }\end{array}$ & $\begin{array}{c}\text { A kritériumoknak } \\
\text { nem felel meg }\end{array}$ \\
\hline \multicolumn{9}{|c|}{ Lakóingatlannal fedezett kitettségek általában } \\
\hline Teljes hitel RW & $20 \%$ & $25 \%$ & 30 & $\%$ & $40 \%$ & $50 \%$ & $70 \%$ & $\begin{array}{l}\text { Ügyfél kockázati } \\
\text { súlya }\end{array}$ \\
\hline $\begin{array}{l}\text { Hitelmegosztás } \\
\text { RW }\end{array}$ & \multicolumn{2}{|c|}{$20 \%$} & \multicolumn{5}{|c|}{ Ügyfél kockázati súlya } & $\begin{array}{l}\text { Ügyfél kockázati } \\
\text { súlya }\end{array}$ \\
\hline \multicolumn{9}{|c|}{ Jövedelemtermelő lakóingatlannal fedezett kitettségek (IPRRE) } \\
\hline Teljes hitel RW & $30 \%$ & $35 \%$ & \multicolumn{2}{|c|}{$45 \%$} & $60 \%$ & $75 \%$ & $105 \%$ & $150 \%$ \\
\hline \multicolumn{9}{|c|}{ Kereskedelmi ingatlannal fedezett kitettségek (CRE) } \\
\hline \multicolumn{9}{|c|}{ Kereskedelmi ingatlannal fedezett kitettségek általában } \\
\hline \multirow[b]{2}{*}{ Teljes hitel } & \multicolumn{2}{|c|}{$\mathrm{LTV} \leq 60 \%$} & \multicolumn{5}{|c|}{ LTV $>60 \%$} & $\begin{array}{c}\text { Kritériumoknak } \\
\text { nem felel meg }\end{array}$ \\
\hline & \multicolumn{2}{|c|}{$\begin{array}{c}\text { Min. (60\%, } \\
\text { ügyfél kockázati } \\
\text { súlya) }\end{array}$} & \multicolumn{5}{|c|}{ Ügyfél kockázati súlya } & $\begin{array}{l}\text { Ügyfél kockázati } \\
\text { súlya }\end{array}$ \\
\hline \multirow[b]{2}{*}{ Hitelmegosztás } & \multicolumn{2}{|c|}{ LTV $\leq 55 \%$} & \multicolumn{5}{|c|}{ LTV $>55 \%$} & $\begin{array}{c}\text { A kritériumoknak } \\
\text { nem felel meg }\end{array}$ \\
\hline & \multicolumn{2}{|c|}{$\begin{array}{c}\text { Min. (60\%, } \\
\text { ügyfél kockázati } \\
\text { súlya) }\end{array}$} & \multicolumn{5}{|c|}{ Ügyfél kockázati súlya } & $\begin{array}{l}\text { Ügyfél kockázati } \\
\text { súlya }\end{array}$ \\
\hline \multicolumn{9}{|c|}{ Jövedelemtermelő kereskedelmi ingatlannal fedezett kitettségek (IPCRE) } \\
\hline \multirow[t]{2}{*}{ Teljes hitel } & \multicolumn{2}{|c|}{$\mathrm{LTV} \leq 60 \%$} & \multicolumn{2}{|c|}{$\begin{array}{c}60 \%<\mathrm{LTV} \\
\leq 80 \%\end{array}$} & \multicolumn{3}{|c|}{$\mathrm{LTV}>80 \%$} & $\begin{array}{c}\text { A kritériumoknak } \\
\text { nem felel meg }\end{array}$ \\
\hline & \multicolumn{2}{|c|}{$70 \%$} & \multicolumn{2}{|c|}{$90 \%$} & \multicolumn{3}{|c|}{$110 \%$} & $150 \%$ \\
\hline \multicolumn{9}{|c|}{ Földtulajdon-vásárlási, fejlesztési és építési (ADC) kitettségek } \\
\hline $\begin{array}{l}\text { Vállalatokkal/ } \\
\text { SPV-vel szembeni }\end{array}$ & \multicolumn{8}{|c|}{$150 \%$} \\
\hline $\begin{array}{l}\text { Előszerződésekkel } \\
\text { fedezett }\end{array}$ & \multicolumn{8}{|c|}{$100 \%$} \\
\hline
\end{tabular}

Forrás: EBA, Bázeli Bizottság

A hitelkockázati fejlett módszerekre vonatkozó változások fö indoka, hogy csökkenteni kell az IRB-módszerekből származó különbségeket, mivel az IRBmódszerek túl összetettek és átláthatatlanok lettek. A kifejezetten erre irányuló vizsgálatok és tesztek is azt mutatták, hogy ha az egyes intézmények belső modelljeivel ugyanannak a portfóliónak a tőkekövetelményét számították, akkor az bankonként meglehetősen eltérő eredményekhez vezetett. Az IRB-módszer alkalmazásához kötődő változások fö elemei, hogy a bankokkal és nagyvállalatokkal szembeni kitettségekre nem lehet majd fejlett IRB-t használni, helyette alap 
IRB-t vagy sztenderd módszert kell alkalmazni. A részesedés jellegü kitettségekre csak a sztenderd módszer használható, illetve az elvárások új vagy megemelt minimum PD, LGD és CCF értékeket (input floor) vezetnek be.

\subsection{A piaci kockázat tőkekövetelménye}

A piaci kockázat témaköre annyiban sajátos, hogy az arra vonatkozó, véglegesnek szánt bázeli elvárásokat a Bizottság nem 2017-ben, hanem 2019 januárjában határozta meg (BCBS, 2019). Ezek a módosítások elsősorban a piaci kockázati sztenderd módszer kockázatérzékenyebbé tételére irányulnak az egyes kockázati osztályokra vonatkozó érzékenységalapú számítások figyelembevételével. A módosítások keretében egyszerüsített módszert vezetnek be a kis kereskedési könyvvel rendelkező intézmények számára, illetve újradefiniálták a kockázati súlyokat az általános kamatláb, valamint a devizaárfolyam-kockázat vonatkozásában.

\subsection{Müködési kockázat}

A működési kockázat új tőkekövetelmény-számítási rendszerének központi eleme, hogy megszűnik az intézmények saját rendszerein alapuló fejlett mérési módszer (AMA) alapján történő tőkekövetelmény-számítás lehetősége. Az eddig alkalmazott többféle módszer helyett csak egy lesz, a sztenderd módszer, amely két feltételezésen alapszik: i) a működési kockázat függ a bank méretétől; ii) ha egy banknak a múltban magas müködési kockázati veszteségei voltak, akkor a jövőben is magasak várhatók. Ennek megfelelően a tőkekövetelményt az árbevétel alapján meghatározott irányadó mutató (Business Indicator - BI) és a veszteségkorrekció (Internal Loss Multiplier - ILM) szorzata adja majd. A kisebb bankoknak (1 milliárd euró irányadó mutató alatt) nem lesz kötelező veszteségkorrekciós tényezőt alkalmazniuk, amelyet a nagyobb bankoknak az elmúlt tíz év müködési kockázati veszteségének adatai alapján kell meghatározniuk.

\subsection{A CVA-kockázat}

A hitelértékelési korrekció (CVA) kiigazítás a partnerrel szemben fennálló ügyletek portfóliójának piaci középértékéhez képest. Ez a korrekció tükrözi az intézmény partnerrel szemben fennálló hitelkockázatának aktuális piaci értékét, nem mutatja viszont a partnerintézménnyel szemben fennálló hitelkockázatának aktuális piaci értékét. A CVA-kockázat a derivatív kitettségek kapcsán számított CVA-értéknek a partner hitelkockázata vagy piaci tényezők miatti változásából származó veszteség kockázata. A végleges Bázel III ajánlás új, a bank méretétől 
is függő CVA-tőkekövetelmény-számítási módszereket vezetett be, megszüntette annak a lehetőségét, hogy a bankok a CVA-kockázat tőkekövetelményét belső modell alapján számítsák ki, és összhangba hozta a CVA és a piaci kockázat tőkekövetelmény-számításához használt módszereket.

\subsection{G-SII megemelt tőkeáttételi mutató}

A Bázel III ajánlás bevezette az alapvető tőke három százalékában meghatározott minimum tőkeáttételi mutató követelményt, a Bizottság azonban a globálisan rendszerszinten jelentős intézmények (G-SIIs) vonatkozásában ezt tovább kívánta szigorítani. Mivel a G-SII-kre a tőkepufferrendszer miatt eleve szigorúbb tőkemegfelelési követelmények vonatkoznak, ezért a Bizottság úgy látta helyesnek, ha ez a megemelt követelményszint a tőkeáttételi mutató szabályozásában is megjelenik. A G-SII intézmények tőkeáttételi mutató követelménye ezért a rájuk meghatározott tőkepuffer 50 százalékának megfelelő mértékben emelkedik (vagyis ha egy bank G-SII tőkepuffer-követelménye 1 százalék, akkor az ő esetében a tőkeáttételi mutató minimumkövetelménye nem 3, hanem 3,5 százalék lesz). Érdekesség, hogy a végleges Bázel III ajánlásnak ez az egyetlen olyan eleme, amit a már elfogadott, és 2021 júniusától alkalmazandó CRR2-szabályok is tartalmaznak. Ráadásul a CRR2 kötelezi az Európai Bizottságot, hogy az 2020 decemberéig megvizsgálja: indokolt lenne-e ezt a követelményt az egyéb rendszerszinten jelentős intézményekre is kiterjeszteni?

\section{AZ EBA-HATÁSTANULMÁNY}

A Bizottság a Bázel III ajánlás módosítását megelőzően számos hatástanulmányt végzett, amelyeknek az eredményei már előrevetítették, hogy egyes bankok esetében a módosítások hatásai elég jelentősek lehetnek. A Bizottság ezért 2018 májusában felkérte az Európai Bankhatóságot (EBA), hogy végezzen el egy olyan hatástanulmányt, amely megvizsgálja a Bázel III végleges ajánlás teljes körü EUimplementálása esetén várható hatásokat, illetve tegyen javaslatokat arra, hogy az EU-implementálás során milyen eltéréseket lát indokoltnak a végleges Bázel III ajánlástól az EU-bankrendszer sajátosságai miatt.

Az EBA a feladat végrehajtása érdekében nagyon részletes adatgyüjtésbe kezdett, amely egyrészt számszaki adatokat tartalmazott, másrészt olyan minőségi információkat, amelyek kiegészítették a mennyiségi adatokból levonható következtetéseket. Az EBA a kérdőívekkel 19 EU-tagállamból összesen 189 bankot keresett meg, amelyek közül 104 került a nagybanki kategóriába (ezek között 8 G-SII, 67 egyéb rendszerszinten jelentős - O-SII és 29 egyéb nagybank), 61 közepes méretü 
és 24 kisméretű intézmény volt. Így elmondható, hogy ezek a bankok összességében az EU bankrendszerének kellően nagy hányadát fedték le. Tekintettel arra, hogy Magyarországról csak egy bank vett részt a felmérésben, ezért az elemzés nem tartalmaz külön magyar adatokat, de az összesített eredményekben a hazai számok is szerepelnek. Azon EU-tagállamok esetében azonban, amelyekből legalább három bank részt vett a hatástanulmányban, az adott országra jellemző hatásokra vonatkozóan is közzétették az eredményeket.

Az EBA végül 2019 augusztusában tette közzé a várható hatásokat (EBA, 2019), valamint a bázeli ajánlás implementálásának módjára vonatkozó javaslatait tartalmazó dokumentumokat.

A számszaki adatok elemzéséből levont legfontosabb következtetéseket a 3. és 4. táblázat foglalja össze.

3. táblázat

A Bázel III teljes implementációja esetén becsült százalékos hatás az alapvető tőke minimumkövetelményében kifejezve

Százalékos hatás

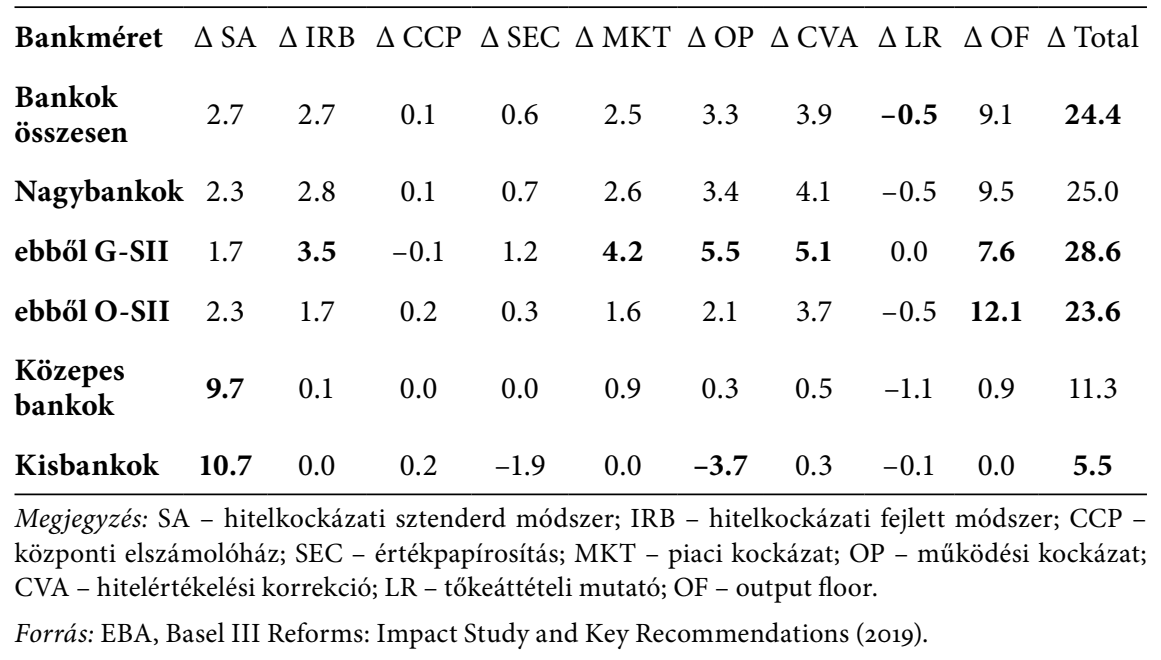




\section{4. táblázat}

Tőkemegfelelési mutatók és tőkehiányok a bankok mérete szerint

\begin{tabular}{|c|c|c|c|c|c|c|c|c|c|}
\hline \multirow[b]{2}{*}{ Bank méret } & \multicolumn{3}{|c|}{$\begin{array}{l}\text { Elsődleges alapvető } \\
\text { tőke (CET1) }\end{array}$} & \multicolumn{3}{|c|}{$\begin{array}{l}\text { Alapvető tőke } \\
\text { (T1) }\end{array}$} & \multicolumn{3}{|c|}{ Teljes tőke } \\
\hline & 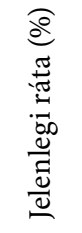 & 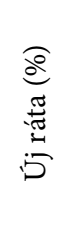 & 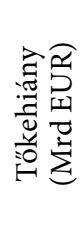 & 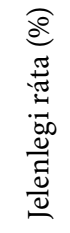 & 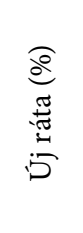 & 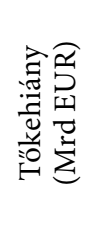 & 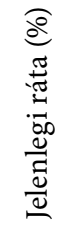 & 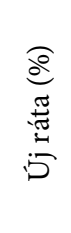 & 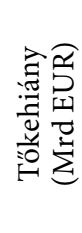 \\
\hline Bankok összesen & 14.4 & 11.5 & 91.1 & 15.3 & 12.3 & 127.5 & 17.9 & 14.3 & 135.1 \\
\hline Nagybankok & 14.2 & 11.4 & 91.0 & 15.2 & 12.2 & 126.8 & 17.8 & 14.2 & 134.1 \\
\hline ebböl G-SII & 12.7 & 9.9 & 53.5 & 13.8 & 10.8 & 69.0 & 16.2 & 12.7 & 82.8 \\
\hline ebből O-SII & 15.4 & 12.5 & 33.6 & 16.3 & 13.2 & 51.5 & 19.2 & 15.6 & 43.8 \\
\hline Közepes bankok & 17.4 & 15.2 & 0.1 & 17.6 & 15.4 & 0.8 & 19.0 & 16.6 & 0.9 \\
\hline Kisbankok & 17.0 & 16.0 & 0.0 & 17.2 & 16.1 & 0.0 & 18.3 & 17.1 & 0.1 \\
\hline
\end{tabular}

Forrás: EBA, Basel III Reforms: Impact Study and Key Recommendations (2019)

A fenti adatok alapján a következő főbb következtetések vonhatók le:

- A Bázel III véglegezés teljes körü EU-átültetése esetén az európai bankok alapvető tőkekövetelménye $24,4 \%$-kal nőne, ezen belül is elsősorban a G-SII $(28,6 \%)$ és az O-SII $(23,6 \%)$ tőkekövetelmény-emelkedése lenne jelentős.

- A G-SII bankok esetében elsősorban a hitelkockázati fejlett módszerben, a piaci kockázatban, a müködési kockázatban, a CVA-kockázatban és az output floor szabályozásban végrehajtott változások eredményezik a tőkekövetelmény-növekedést.

- Az O-SII bankok esetében is hasonló a helyzet, de ott az output floor bevezetésének kiemelten jelentős a hatása.

- A közepes és a kisbankok esetében szinte kizárólag csak a hitelkockázati sztenderd módszerben végrehajtott változtatásoknak van alapvető tőkekövetelményt növelő hatása (ez azért is van így, mert ezek a bankok elsősorban sztenderd módszert használnak tőkekövetelmény-számításra).

- A kisbankok esetében a működési kockázat tőkekövetelmény-számítási szabályainak egységesítése miatt átlagosan inkább csökken az alapvető tőkekövetelmény, mint növekszik. 
- A tőkeáttételi mutató számítási módszereinek módosításai miatt a G-SII bankok kivételével minden banktípus esetében csökken az alapvető tőkekövetelmény, de a G-SII bankok esetében sem okoz növekedést.

- A Bázel III teljes körű implementálása esetén az EU-bankoknak összesen 135,1 milliárd euró alapvető tőkehiánya keletkezne, vagyis legalább ennyi tőkeemelésre lenne szükség ahhoz, hogy a bankok elérjék a minimum tőkekövetelményeket. Ez a hiány szinte kizárólag csak a nagybankoknál keletkezik, a kis- és közepes méretű bankoknál az alapvető tőke hiánya elhanyagolható mértékű.

Az EBA a részletes hatástanulmányában ezeket a fő megállapításokat további részletes információkkal egészíti ki, amelyek közül a legfontosabbak a következők:

- A mintában szereplő bankok teljes tőkemegfelelési mutatója jelenleg 17,9\%, ez az érték a Bázel III ajánlás teljeskörü implementálása esetén 14,3\%-ra csökkenne.

- A tőkekövetelmény növekedés összetétele megfelel annak az eredeti szabályozói szándéknak, hogy a kockázatosabb tevékenységeknek magasabb legyen a tőkekövetelménye. Ennek megfelelöen ezek a tőkekövetelmény-növekedések olyan, az eredeti szabályozói szándékot is tükröző változások, amelyek növelik majd az EU bankrendszerének biztonságát (pl. részesedések magasabb kockázati súlya, belső modellek alkalmazásának korlátozása).

- A hitelkockázati sztenderd módszer esetében - ezek a változások elsősorban a kis- és közepes méretű bankokat érintik - az alapvető tőkekövetelmény-növekményt a részesedések, az alárendelt kölcsöntőke és a bankokkal szembeni kitettségek kockázati súlyainak a növekedései eredményezik.

- A hitelkockázat tőkekövetelmény-számítására fejlett módszert (IRB-t) alkalmazó bankok esetében a tőkekövetelmény-növekedést elsősorban a fejlett módszerek használatának a korlátozása okozza. A fejlett módszerek alkalmazásának a korlátozása miatt ezek a bankok kénytelenek kevésbé fejlett módszereket alkalmazni, amelyek alapján magasabb a számított tőkekövetelmény. A mintában szereplő 79 IRB-t alkalmazó bank közül 40 esetében olyan jelentős a változás, hogy az már tőkehiányt is okoz, vagyis ezeknek a bankoknak fel kell készülniük ennek a pótlására vagy új tőke bevonásával, vagy belső tőkeképzéssel. Bár az EBA-hatástanulmány magyar adatokat részleteiben nem tartalmaz, de meg kell jegyeznünk, hogy az output floor hatása a hazai bankokra inkább csak közvetett (vagyis inkább csak a külföldi anyabankot érinti), mivel a hazai magas múltbeli nemteljesítési adatok miatt a fejlett módszerek általában a sztenderd módszernél magasabb tőkekövetelményt adnak. 
- A CVA-kockázat tőkekövetelményének esetében a növekedés fö oka az, hogy az EU a saját szabályozásában, vagyis a CRR 382. cikkében jelenleg a bázeli ajánlástól eltérően számos kitettséget mentesít a CVA-kockázat tőkekövetelmény-számítása alól (pl. egyes nem pénzügyi szerződő felekkel kötött ügyletek, csoporton belüli ügyletek), amely mentesítéseket a bázeli ajánlás teljes körü átvétele esetén el kellene törölni, ez viszont tőkekövetelmény-emelkedést jelentene.

- A piaci kockázati tőkekövetelmények esetében az EBA azt javasolja, hogy a tényleges tőkekövetelmény-változás hatását a 2019-es adatok alapján újra meg kell vizsgálni, mert az új, 2019 januárjában kiadott bázeli ajánlás hatásainak a felméréséhez új adatszolgáltatásra lenne szükség.

- A müködési kockázati tőkekövetelmény-növekedés esetében a hatás fö oka az ILM-érték bevezetése, ennek következtében az elsősorban a nagybankokat érinti.

A fenti adatokat és következtetéseket annak a figyelembevételével kell értelmezni, hogy a végleges Bázel III ajánlás bevezetésének tervezett időpontja 2022. január 1. A legtöbb szabályt ráadásul ötéves átmeneti időszak alatt fokozatosan vezetik be, vagyis a végleges követelményeknek csak 2027-től kezdődően kellene megfelelni. Az is erősen valószínüsíthető, hogy a végleges Bázel III ajánlás EU-implementálásakor, vagyis a CRD és a CRR megfelelő módosítása során az elvárásokat nem teljes mértékben veszik át, hanem annak során olyan EU-eltéréseket is alkalmaznak, amelyeket a EU-bankrendszer sajátosságai indokolnak. Ráadásul a Bázel III ajánlás szigorúbb követelményei miatt a nemzeti felügyeleti hatóságok módosíthatják a 2. pillér keretében eddig elöírt tőkekövetelményeket, a makroprudenciális felügyeleti hatóságok pedig csökkenthetik a már elöírt rendszerkockázati tőkepuffereket. Az EBA-hatástanulmány valószínüsíthetően túlbecsüli a piaci kockázati tőkekövetelményt, mivel azt a Bizottság 2019. januári anyaga is módosította már. A hatástanulmány eredményeinek értékelése során pedig azt is tudomásul kell venni, hogy az statikus mérlegeket vesz figyelembe. Ezzel szemben várható, hogy a bankok a szabályozás ismeretében módosítanak majd üzleti stratégiájukon, hogy ezáltal is csökkentsék a tőkekövetelmény és a tőkehiány összegét. A végleges hatás ezért a most előre jelzetthez képest jóval alacsonyabb is lehet, illetve a bankoknak amúgy is még 8 évük van arra, hogy a szükséges tőkebevonásokat elvégezzék.

Az EBA az Európai Bizottság kérésének megfelelően egy olyan alternatív forgatókönyv alapján is kiszámolta a várható hatásokat, amelyben azzal számoltak, hogy a Bázel III ajánláshoz képest már eddig is alkalmazott EU-eltérések a továbbiakban is fennmaradhatnak. Ilyennek minősül különösen a kis- és középvállalkozásokkal szembeni kitettségekre vonatkozó, kedvezményes 0,7619-es szorzótényező 
(SME-faktor), a CVA-kockázat alóli kivételek, illetve a bankspecifikus veszteségadatok (ILM-faktor) figyelmen kívül hagyása a müködési kockázat tőkekövetelmény-számítása során. Ezen feltételek mellett a hatástanulmány által feltárt tőkehiány összege is jelentősen csökkenne (pl. ha a CVA-mentesítések megmaradnak, akkor a 135,1 Mrd euró helyett csak 116,9 Mrd euró lenne a tőkehiány).

\section{AZ EBA AJÁNLÁSAI \\ A BÁZEL III VÉGLEGES AJÁNLẤS EU-IMPLEMENTÁLÁSÁRA}

Az Európai Bizottság felkérése kifejezetten tartalmazta azt, hogy az EBA a felmérés eredményeképpen tegyen javaslatokat a végleges Bázel III ajánlás EU-implementálásának módjára. Az EBA a közzétett dokumentumaiban ezért részletes ajánlásokat fogalmazott meg erre vonatkozóan, amelyek közül a legjelentősebbek az alábbiak.

\section{1. Általános ajánlások}

Az EBA általános javaslatként fogalmazta meg, hogy a Bázel III EU-implementálásának a fó elve az legyen, hogy az EU az abban foglalt ajánlásokat teljeskörüen alkalmazza, és csak azokban az esetekben kerüljön sor eltérésekre, amikor azok feltétlenül indokoltak. Az EU jelenleg amúgy sem áll jól a Bázel III ajánlásnak való megfeleléssel, mert a legutóbbi, még 2014-ben folytatott vizsgálat során a Bizottság úgy ítélte meg, hogy az EU szabályozása lényegében nem felel meg (materially non-compliant) a Bázel III ajánlásban foglaltaknak (BCBS, 2014). Ezek az eltérések az EU-bankrendszer hitelességét és megbízhatóságát sem erősítik. Ezért az EBA fontosnak tartja, hogy az eltérések száma csökkenjen, amire a végleges Bázel III ajánlás implementálása megfelelő alkalmat jelent. A hitelesség erősítése pedig bőven ellensúlyozza az eltérések alkalmazásával nyerhető tőkekövetelmény-megtakarításból származó előnyöket. Az EBA azt is fontosnak tartja, hogy a végleges Bázel III ajánlás EU-implementálása olyan módon történjen meg, hogy az abban foglaltak alkalmazása - a megfelelő átmeneti rendelkezésekkel együtt - már 2022-től kezdődjön meg a bázeli ütemtervnek megfelelően.

\subsection{A hitelkockázattal kapcsolatos ajánlások}

A végleges Bázel III ajánlás több ponton is lehetöséget ad arra, hogy még a sztenderd módszert alkalmazó bankok is csökkenthessék a külső hitelminősítőktől való függőségüket, és a ratingek helyett inkább belső minősítéseket alkalmaz- 
zanak. Több, a Bizottság tagjai közé tartozó ország ugyanis a globális pénzügyi válságot követően olyan intézkedéseket hozott, amellyel korlátozták a külső hitelminősítők által adott ratingeknek a sztenderd módszerben való felhasználhatóságát. Az EBA azonban azt javasolja az Európai Bizottság számára, hogy a CRR-nek a sztenderd módszerre vonatkozó szabályai továbbra is a külső hitelminősítők ratingjeit alkalmazzák, aminek az a fö oka, hogy ez az eljárás biztosítja leginkább az azonos számítási módot és az egyenlő versenyfeltételeket.

Az ingatlannal fedezett kitettségek kockázati súlyozása során eddig jelentős eltérés volt a bázeli és az EU-szabályok között amiatt, hogy a CRR lehetővé tette az ilyen kitettségek kitettségi osztályok közötti megosztását (loan splitting). Ez a gyakorlatban azt jelentette, hogy ha a jelzáloghitel egy része megfelelt a kedvezményes kockázati súlyozási feltételeknek, akkor azt a részét lehetett 35 százalékos kockázati súllyal, a fennmaradó részét pedig az adós szerinti kockázati súllyal (lakossági ügyfél esetében 75 százalék) figyelembe venni. A bázeli ajánlás viszont azt az eljárást alkalmazta, hogy egy jelzáloghitel vagy megfelel a feltételeknek (pl. 80 százalék alatti LTV-érték), és akkor alkalmazható rá a 35 százalékos kockázati súly, vagy nem, és akkor a teljes kitettséget 75 százalékkal kell súlyozni. Ez a jelentős eltérés most mindenképpen csökkenni fog, mert a végleges Bázel III ajánlás már maga is lehetővé teszi majd a jelzáloghitelek kitettségi osztályok közötti megoszthatóságát, és az EBA javasolja is ennek az új bázeli eljárásnak a CRR-ben történő alkalmazását.

Az EBA egyik nagyon fontos ajánlása az, amelyik azt javasolja a Bizottságnak, hogy az EU-szabályozás ne tartalmazzon a bázeli ajánláshoz képest további kedvezményeket a kis- és középvállalatoknak nyújtott hitelekhez, valamint az infrastrukturális beruházások finanszírozásához kapcsolódóan. Az SME-faktor (o,7619) alkalmazása eddig az egyik legjelentősebb eltérés volt a bázeli és az EUkövetelmények között. A végleges Bázel III ajánlás azonban most bevezet majd egy o,85 százalékos kockázati súlyt az SME-kitettségekre, ezért az EBA a továbbiakban nem tartja szükségesnek az eddig a CRR-ben alkalmazott SME-faktor fenntartását. Fontosnak tartja az EBA ugyanakkor az SME-definíció egységesítését: az EU ne alkalmazza azt a Bázel III ajánlásban szereplő lehetőséget, hogy az ajánlást átültető országok még konzervatívabb SME-definíciót is alkalmazhatnak. Külön érdekessége ennek az EBA-ajánlásnak, hogy az infrastrukturális beruházásokat támogató kedvezményes, 0,75-ös kockázati faktort (ISF) éppen most ültették be a CRR2-be, de az EBA máris a törlését javasolja.

Az ajánlásaiban az EBA javasolja fenntartani azt a CRR-ben jelenleg is alkalmazott bázeli ajánlásoktól való eltérést, ami a csoporton belüli részesedéseknek a szavatolótőkéből történő levonás alóli mentesítésére vonatkoznak.

Az értékpapír-finanszírozási ügyletekből származó partnerkockázati kitettségekre alkalmazandó új bázeli ajánlások esetében azok teljes EU-implementálását 
javasolja az EBA. Ugyanakkor felveti annak a szükségességét, hogy a bázeli ajánlásban foglalt küszöbértékszabályok (minimum haircut floors) EU-alkalmazását még további vizsgálatok előzzék meg.

\subsection{A müködési kockázattal kapcsolatos ajánlások}

Az EBA már korábbi anyagaiban is azt az álláspontot képviselte, hogy még a fejlett módszer (AMA) kivezetését követően is fenn kell tartani a megfelelő ösztönzőket arra, hogy a bankok csökkentsék a müködési kockázatból származó veszteségeiket. Ennek megfelelően az EBA támogatja, hogy az ilyen veszteségek historikus adatai minél több bank esetében szerepeljenek a müködési kockázat tőkekövetelmény-számításában. Az EBA ezért azt a javaslatot tette az Európai Bizottságnak, hogy a végleges Bázel III ajánlás által bevezetendő ILM-szorzótényezőt - amelyet az elmúlt 10 év veszteségadatai alapján kell kiszámítani - minden (2. és 3. besorolási osztályba tartozó) közepes és nagybank köteles legyen alkalmazni, illetve még a kisbankok számára is lehetővé kellene tenni a figyelembevételét, mivel ezáltal a megfelelő működési kockázatkezelő eljárásokkal rendelkező hitelintézetek csökkenteni tudnák a tőkekövetelményüket.

A végleges Bázel III ajánlás a működési kockázati veszteségadatok gyűjtése során azt várja el, hogy abba minden 20 ooo euró feletti veszteségadat bekerüljön. Nemzeti hatáskörben ugyanakkor a közepes és nagybankok esetében lehetőséget ad ennek a küszöbértéknek a 100 ooo euró értékre emelésére. Az EBA azt javasolja a Bizottságnak, hogy a bázeli ajánlások implementálása során a CRR-be kerüljön be ez a nemzeti diszkréciós lehetőség.

\subsection{A CVA-kockázat}

A CVA-kockázat kapcsán az EBA jelenleg nem fogalmazott meg konkrét ajánlást, és azt javasolja az Európai Bizottságnak, hogy a CVA-kockázat tőkekövetelményszámítására vonatkozó EU-jogszabályok kidolgozását még további elemzések előzzék meg.

\subsection{Output floor}

Az EBA egyértelműen azon az állásponton van, hogy a végleges Bázel III ajánlásban szereplő output floort a CRR-ben is alkalmazni kell. A konkrét szabályok kidolgozása során viszont az EBA felhívja arra a figyelmet, hogy a CRD olyan tőkepuffer-követelményeket is tartalmaz, amelyek a Bázel III ajánlásban nem szerepelnek (rendszerkockázati és O-SII-tőkepufferek). A végleges Bázel III aján- 
lás értelemszerủen nem tartalmaz szabályokat ezekre nézve, de az EBA hoszszas egyeztetéseket követően végül azt a javaslatot tette, hogy az output floorkövetelményt ezekre a tőkepufferekre is alkalmazni kell. Ez a gyakorlatban azt jelenti, hogy a tőkepuffer mértékének a meghatározása során nem a belső modell által számított kockázattal súlyozott eszközértéket kell alapul venni, hanem azt korrigálni kell a sztenderd módszer szerint számított output floorral is. Ez az eljárás azon bankok esetében, amelyeknél az output floornak tényleges korlátozó hatása van - vagyis a belső modell alapján számított tőkekövetelmény kevesebb, mint a sztenderd módszer szerint számított tőkekövetelmény 72,5 százaléka -, magasabb tőkepuffer-követelményt fog eredményezni, mivel a tökepuffert is az output floorral korrigált, vagyis a magasabb kockázattal súlyozott eszközérték alapján kell kiszámítani. Az EBA javaslata szerint ugyanezt az output floorral korrigált kockázattal súlyozott eszközértéket kellene alapul venni a felügyeleti felülvizsgálati folyamatban a 2. pilléres tőkekövetelmény meghatározása során is.

\section{TOVÁBBI ADATKÉRÉS ÉS NYILVÁNOS KONZULTÁCIÓ}

Az EBA által készített hatástanulmány és implementációs ajánlások ismeretében az Európai Bizottság úgy döntött, hogy további vizsgálatok elvégzésére kéri fel az intézményt. Az EBA az ajánlásai között azt javasolta a Bizottságnak, hogy az output floor-követelmény a konszolidáció minden szintjén érvényesüljön. Tekintettel arra, hogy az output floor alkalmazása az európai bankokat érő tőkekövetelmény-növekmény egyik legfontosabb tényezője, a Bizottság arra kérte az EBA-t: részletes adatokkal mutassa be, hogy az output floor mindhárom (egyedi, szubkonszolidált, konszolidált) szinten történő alkalmazásának milyen konkrét számszaki hatásai lennének. Ezen túl a Bizottság azt is kéri az EBA-tól, hogy vizsgálja meg a részesedések esetében a tőkekövetelményeknek a csoporton belüli kitettségekre való lehetséges kiterjesztésének a hatásait, illetve tekintse át, hogyan lehetne ezekre a kitettségekre a tőkekövetelmény-számítást kockázatérzékenyebbé tenni. Szintén javaslatokat vár az Európai Bizottság az EBA-tól a speciális hitelezési kitettségek esetében alkalmazott módszerek kockázatérzékenységének javítására, és hogy mérje fel a lehetséges MREL-nemteljesítések várható mértékét. Az EBA már megkezdte ezeknek az újabb felkéréseknek a teljesítését, a válaszok elkészítése a közeljövőben várható. 
A Bizottság ezen túl meghirdetett egy nyilvános konzultációt is², ennek a keretében a piaci szereplők 2020. január 3-ig küldhetnek véleményt azokról a kérdésekről, amelyek a végleges Bázel III ajánlás EU-implementálását célozzák.

\section{6. ÖSSZEFOGLALÁS}

Az EBA az Európai Bizottság felkérésére elvégzett hatástanulmányát és implementálási ajánlásait nyilvánosan elérhető, több száz oldalas dokumentumokban tette közzé. Az EBA jelenleg is dolgozik még egyes témakörökben, így különösen a Bizottság újabb felkérésében szereplő kérdések kapcsán további hatástanulmányok és ajánlások elkészítésén. A Bizottság nyilvános konzultációt folytat a végleges Bázel III ajánlás EU-implementálásának legfontosabb kérdéseiről, amelyek alapján a későbbiekben megkezdődhet a $\mathrm{CRR}_{3}$ és a CRD6 jogalkotási javaslatok kidolgozása. Az Európai Bizottságnak mindenképpen sietnie kell a jogszabálymódosítási tervezetek elkészítésével, mert a jogi szövegek előkészítésének, a megfelelő (EU Parlament és a Tanács) döntéshozó szervezeteken való átfuttatásának és az elegendő felkészülés szükségszerü biztosításának mind jelentős időigénye van. Ezek kétségessé teszik, hogy ezeket az új szabályokat 2022. január 1-től az EU-ban valóban alkalmazhatják. Az a körülmény sem javítja a helyzetet, hogy a CRR2, CRD5 és BRRD2 módosításai miatt az EBA-nak időközben 109 különböző témakörben kellene végrehajtási rendelettervezetet, ajánlást, illetve véleményt kidolgoznia, ami extrém szintü terhelést jelent mind az EBA, mind a Bizottság számára. Pozitív fejlemény azonban, hogy az EBA-hatástanulmány elvégzése jelentősen megkönnyíti a döntéshozó szervek munkáját, mert annak az alapján jól megbecsülhető, hogy az egyes döntési alternatíváknak milyen számszerüsíthető következményei lehetnek.

2 Alignment EU rules on capital requirements to international standards (prudential requirements and market discipline), https://ec.europa.eu/info/law/better-regulation/initiatives/finance-2019basel-3/public-consultation_en. 


\section{HIVATKOZÁSOK}

BCBS (2014): Regulatory Consistency Assessment Programme (RCAP), Assessment of Basel III regulations - European Union. December, https://www.bis.org/bcbs/publ/d30o.pdf.

BCBS (2017): Basel III: Finalising post-crisis reforms. December, https://www.bis.org/bcbs/publ/ d424.pdf.

BCBS (2019): Minimum capital requirements for market risk. January, https://www.bis.org/bcbs/ publ/d457.pdf.

EBA (2019): EBA advises the European Commission on the implementation of the final Basel III framework. August, https://eba.europa.eu/eba-advises-the-european-commission-on-theimplementation-of-the-final-basel-iii-framework.

EC (2013): Capital Requirements - CRD IV/CRR - Frequently Asked Questions. https://ec.europa. eu/commission/presscorner/detail/en/MEMO_13_69o, July. 